\title{
Research on China's Tobacco Industry Value Chain
}

\author{
Zhihua ZHANG ${ }^{1, a}$, Shouwen $\mathrm{JI}^{2, \mathrm{~b}}$, Zengrong $\mathrm{SU}^{3, \mathrm{c}}$ and Yanghua $\mathrm{GAO}^{4, \mathrm{~d}}$ \\ ${ }^{1,4}$ NO.288, Jianguo south Road, Hangzhou, Zhejiang Province, China \\ ${ }^{2,3}$ School of Traffic and Transportation, Beijing Jiaotong University, China \\ azzh@zjtobacco.com, bjishouwen@126.com, ${ }^{\text {c12125686@bjtu.edu.cn, }{ }^{d} y h g a o @ z j u . e d u . c n ~}$
}

Keywords: tobacco industry; value chain; cigarette

\begin{abstract}
The paper analyzed the current situation and development trends of China's tobacco industry and established a value chain model. At last, the paper determines the enterprise competitive advantage by decomposing the activities.
\end{abstract}

\section{Introduction}

China's tobacco industry has made remarkable achievements since the tobacco monopoly system was carried out 30 years ago. With the market-oriented reform, competition in tobacco industry becomes more and more fierce. The structure and mode of value chain have a crucial influence on enterprise's costs and profits. In order to keep the enterprise's competitiveness, it's extremely urgent to identify and confirm its competitive advantage.

\section{The current situation and development trends of China's tobacco industry}

China's tobacco industry has a large market but the total demand will gradually decline. According to the Ministry of Health's National Health Services Survey, smoker's number in China is 270 million in 2009 and $62 \%$ of them smoke 20 or more cigarettes every day. Tobacco products are daily consumer goods related to personal hobby. The combined cost of smoking is increasing because of health conscious and high tobacco taxes. ${ }^{[1]}$ At the same time, smoking behaviors are restricted and smoking environment will gradually disappear in the progress of urbanization. Under the two aspects' synthetic action, smoking rate and average consumption will decline continuously.

Buyer market is established and internal and external competition is intensifying. With reducing tariffs and removing non-tariff barriers, China's tobacco market will unavoidably encounter the competition and challenge from Philip Morris, British American Tobacco, Japan Tobacco Company and other transnational tobacco enterprises. Non-price competition becomes the trend and strategy in tobacco enterprises, such as expanding product publicity, tracking product quality, service quality improvement and sales network construction. China's cigarette market has been transformed into an entirely buyer market.

Scale competitiveness is low and collectivization development patterns remains to be completed. National Tobacco Monopoly Bureau has constructed tobacco enterprise groups to make full use of scale economy. However, there exist some problems. Firstly, government behavior is obvious in tobacco group's establishment and operation, which doesn't comply with the laws of economics. Secondly, there exist misunderstandings of the enterprise group. Some local tobacco groups applied for state policy in the name of enterprise group. Finally, tobacco group's management autonomy and property rights are not clear so that collectivized business operation is difficult to put into effect.

\section{The value chain model of China's tobacco industry}

Since value chain theory was proposed by Prof. Mike Porter in 1985, it has become an effective tool for the study of competitive advantage ${ }^{[2]}$. According to value chain theory, the competitive advantage of enterprise entity comes from its procurement, production and marketing activities ${ }^{[3]}$. 
We can analyze key values and economic effects through decomposition of different activities based on value chain.

The tobacco value chain consists of four entities: tobacco grower and other suppliers, tobacco industry-company, tobacco business-company, Tobacco Monopoly Bureau and the government. Tobacco grower and other suppliers sell raw and supplemental materials to tobacco industry-company, gaining profit from the balance between production cost and selling price of materials. Tobacco industry-company produces finished cigarette products from raw and supplemental materials, getting revenue from the value-added benefits in processing. Tobacco business-company sells cigarette products to customers, getting profit from the difference in retail price and finished goods' price. At last, the revenue of Tobacco Monopoly Bureau and government comes from tobacco consumption tax, value-added tax and other forms of taxation.

According to Porter value-chain theory, China's tobacco industry value chain model is shown in Figure 1.

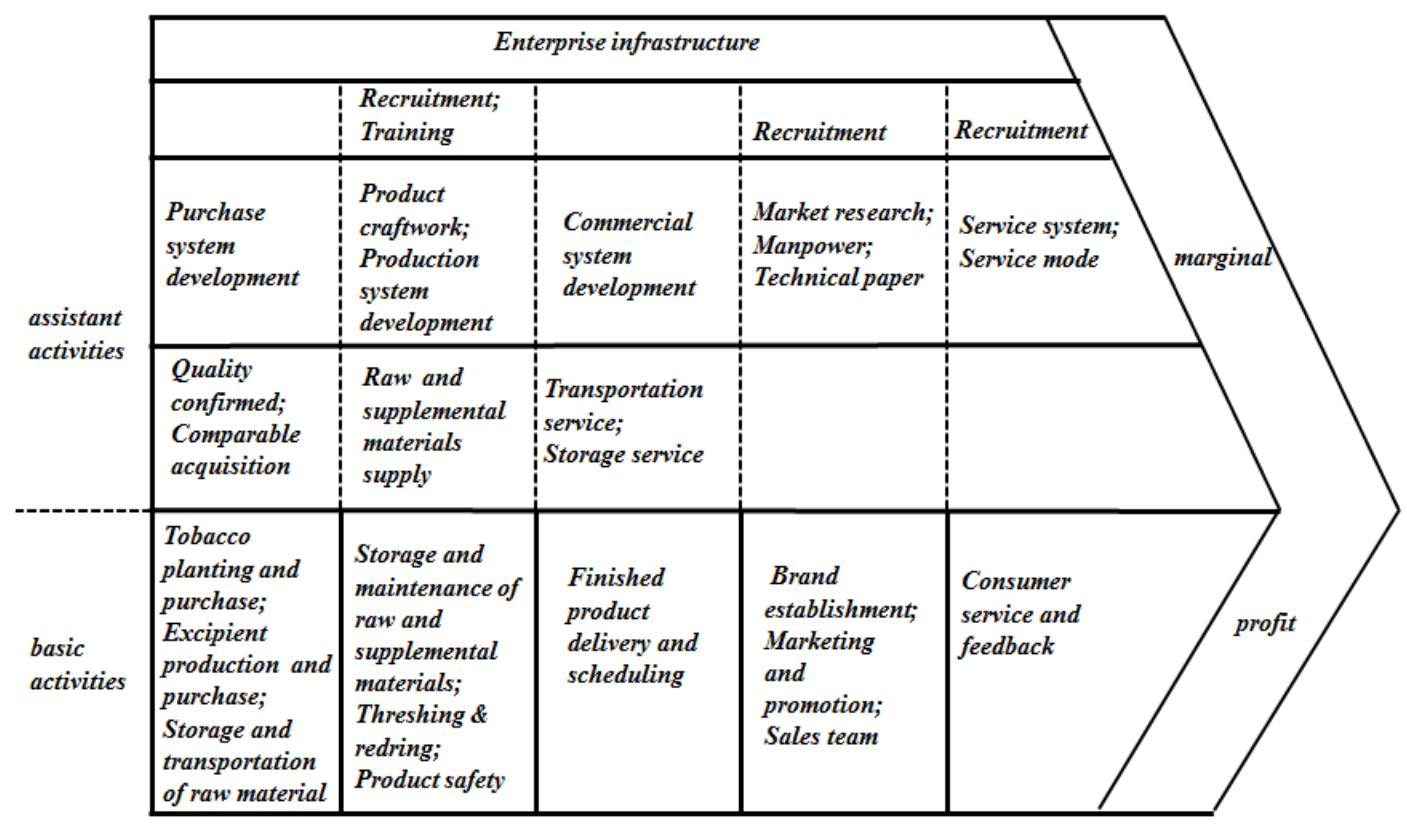

Fig. 1 Tobacco value chain model

The formation of tobacco value chain can be divided into three stages: first is supply link that consists of tobacco grower and other suppliers; second is production link composed of the tobacco industry and its affiliated companies; third is sales link that consists of tobacco business-company and its subsidiary distributors of all levels. In addition, government behavior is an important part in tobacco value chain because of the monopoly system. The formation of tobacco value chain corresponding to the entities is shown in Figure 2.

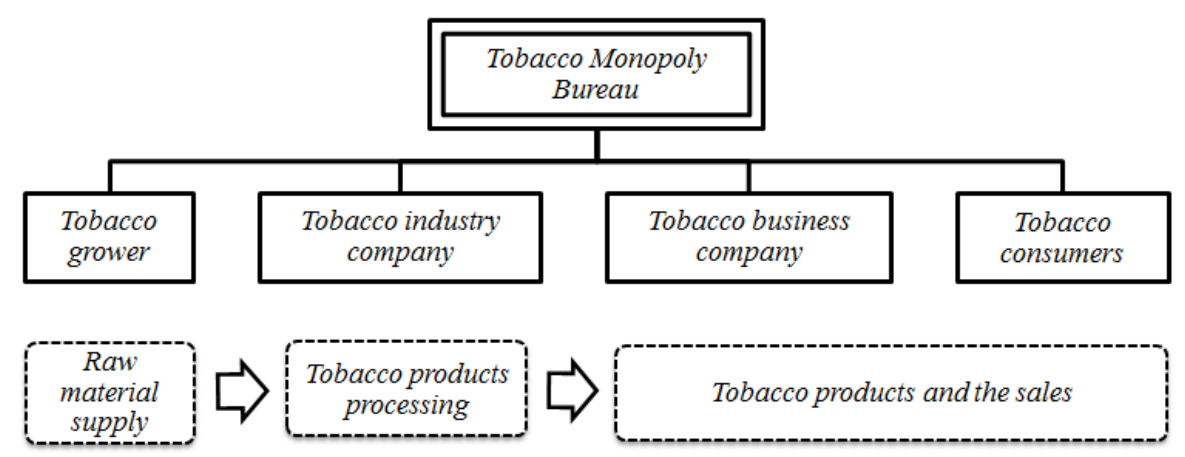

Fig. 2 The formation of tobacco value chain 


\section{Detailed analysis based on the decomposition mode}

The analysis of every link in tobacco value chain is as follows.

\section{Raw material supply}

The planting area of tobacco in China is around 15 million mu, producing about 35 million quintals of tobacco leaves. It can satisfy the demands of tobacco industry. However, because of the decreasing purchase price of tobacco leaf, the enthusiasm of farmers has dropped year by year. In order to improve the famers' positivity, some local companies have attempted to cooperate with them in cultivation. But now the scale is not large.

\section{Production of tobacco products}

In the national 29 key reconstruction enterprises, the equipment advancement has approached or reached the international first-class level. However, there exist some problems in the production. Firstly, because of the lack of early taxation system local government has devoted to expand the production scale. This leads to serious idle status in our tobacco production and it is not fully contained at present. Secondly, the utilization of resource is low, as is reflected in the low service efficiency of the facilities. What's more, the concentration rate of China's tobacco industry is low and the profitability is weak. Four-firm concentration rate is about $16 \%$, which is significantly lower than the $94 \%$ of the U.S. market and $74 \%$ of the Japanese market. Some small cigarette enterprises suffer heavy losses due to the prominent economies of scale. These factors have seriously affected China's tobacco industry's competitiveness.

\section{Tobacco products and the sales}

The production of cigarette is huge and it has complete brand categories. According to the statistics of 2011, Chinese cigarette production achieved 2.44 trillion sticks a year, accounting for $40.8 \%$ of the world. The cigarette is divided into five levels by allocation and transfer price, satisfying demands of different consumer groups.

Though the account of cigarette brands in China has been compressed from 758 in 2002 to 173 in 2007, a united market hasn’t been formed in cigarette field, coupled with long-term blockade and protection. Most brands are popular only in specific region, and real circulation of certain brand in the country is one in a million.

There is a rapid development in the construction of China's tobacco sales network. A total number of 16499 cigarette wholesale dots have been built ever since State Tobacco Monopoly Bureau proposed the construction of a national network. It covers more than 200 cities and 35,139 towns, equipped with fifty thousand delivery vehicles, and delivering goods for more than 3.6 million cigarette retailers. ${ }^{[4]}$ Thus, a well-organized cigarette sales network system with standardized operation across the urban and rural areas has been formed. Through the construction China National Tobacco Corporation firmly holds the control of initiative of domestic cigarette market, and that is important for purification and steadiness of domestic market ${ }^{[5]}$. While in cigarette circulation, the operation is relatively closed and logistics cost is high.

After comprehensive analysis of every procedure mentioned above, a list of competitive situation has been worked out. It is shown in Table 1 .

Table1 Competitive situation of tobacco value chain

\begin{tabular}{l|l|l}
\hline \hline Stages & advantages & disadvantages \\
\hline \hline $\begin{array}{l}\text { Raw Material } \\
\text { Supply }\end{array}$ & $\begin{array}{l}\text { Tobacco industry has large } \\
\text { output, diversified products and } \\
\text { high quality-price ratio; } \\
\text { Planting plan is made } \\
\text { according to demand; } \\
\text { Provide technical service for } \\
\text { the grassroots. }\end{array}$ & $\begin{array}{l}\text { The degree of cooperative } \\
\text { relationship with farmers is low; } \\
\text { Tobacco supply's stability is } \\
\text { limited in some extent. }\end{array}$ \\
\hline $\begin{array}{l}\text { Production of } \\
\text { Tobacco } \\
\text { Products }\end{array}$ & $\begin{array}{l}\text { Equipment advancement of } \\
\text { China's Tobacco Industry has } \\
\text { approached or reached }\end{array}$ & $\begin{array}{l}\text { Serious idle status; } \\
\text { Low utilization rate; } \\
\text { Low concentration rate; }\end{array}$ \\
\hline \hline
\end{tabular}




\begin{tabular}{l|l|l}
\hline \hline & $\begin{array}{l}\text { international first-class level; } \\
\text { It has high capacity. }\end{array}$ & Tintype enterprise's existence; \\
\hline Tobacco & $\begin{array}{l}\text { Cigarette safety is promoted; } \\
\text { Products }\end{array}$ & $\begin{array}{l}\text { Relatively closed logistics } \\
\text { and Sales } \\
\text { is developed bution; }\end{array}$ \\
& $\begin{array}{l}\text { Commercial network is well } \\
\text { organized and normatively } \\
\text { operated; } \\
\text { It firmly holds the initiative of } \\
\text { market sales. }\end{array}$ & $\begin{array}{l}\text { Low utilization rate of social } \\
\text { logistics resources. }\end{array}$ \\
\hline \hline
\end{tabular}

\section{Summary}

In the paper, we have established the model of tobacco value chain and determined the competitive advantage of tobacco industry. The research is important for competitiveness promotion.

\section{References}

[1] Zhu Jun-feng. Research on development of China's tobacco industry[D]. Jilin Agricultural University, 2008.

[2] Huang Dong-bing, Guo Fei-fei. Research on value chains: A case of the tobacco enterprise[C]. In: ICMMME - 2011 International Conference on Mechanical Materials and Manufacturing Engineering.

[3] Li Lian-hong, Luo Xiao-yong. Study of cigarette logistics optimization based on value chain analysis[C]. In: ICIEEM 2010 - 17th International Conference on Industrial Engineering and Engineering Management.

[4] Liu Ming-jun; An Shi-quan; Shi Quan-sheng. A study on integration of tobacco industry informatization base on SOA [C]. in: Information Management, Innovation Management and Industrial Engineering (ICIII), 2010 International Conference

[5] Empirical research on competitiveness of Chinese tobacco industry[J]. Collected Essays on Finance and Economics, 2008(1):22-29. 